\title{
A comprehensive approach to design molded culinary products using cottage cheese for school meals
}

\section{Uma abordagem abrangente para projetar produtos culinários moldados à base de queijo cottage para refeições escolares}

\author{
Shamkova Natalia Timofeevna1, Usatikov Sergey Vasilievich², \\ Dobrovolskaya Anastasia Vladimirovna ${ }^{1}$, Abdulhamid Asmaa Muhsen ${ }^{1 *}$ (1)
}

${ }^{1}$ Kuban State Technological University, Department of Public Catering and Service, Krasnodar - Russia

${ }^{2}$ Kuban State Technological University, Department of General Mathematics, Krasnodar - Russia

*Corresponding author: Abdulhamid Asmaa Muhsen, Kuban State Technological University, Department of Public Catering and Service, st. Moskovskaya 2, 350072, Krasnodar - Russia, e-mail: asmaa.abdulhamid1986@gmail.com

Cite as: Timofeevna, S. N., Vasilievich, U. S., Vladimirovna, D. A., \& Muhsen, A. A. (2021). A comprehensive approach to design molded culinary products using cottage cheese for school meals. Brazilian Journal of Food Technology, 24, e2020218. https://doi.org/10.1590/1981-6723.21820

\begin{abstract}
Among the main challenges regarding the food industry, it could be noted that it is necessary to make food products with the required quality and affordable cost. Computing modeling methods solved such tasks by optimizing food recipes based on specific product criteria. However, the problem of optimizing school meals still needs to be addressed. Cottage cheese and culinary products are valuable sources of protein and calcium. They are particularly in demand for schoolchildren's nutrition. This research aimed to develop molded culinary products with cottage cheese (cheese pancakes) based on the criteria convolution method using the Harrington-Mecher desirability function, i.e., a generalized desirability function in order to meet the physiological needs of school-aged children. The components used were cottage cheese, two additives from Jerusalem artichoke: (M1: «Jerusalem artichoke, pumpkin, pear» or M2: Jerusalem artichoke, quince, mountain ash), egg, and dry components (barley flakes or oat flour). Components were combined at specific ratios; the masses obtained were subject to structural-mechanical and sensory analysis. To determine the optimal equation of the dependence of the critical shear stress (yield stress) regarding the quantitative recipe composition, regression analysis was conducted, followed by Multi-criteria optimization based on Harrington's desirability function. Two cheese pancake recipes were proposed, as they showed optimum quality characteristics of the final product: Recipe 1 (\%): Cottage cheese 74.0, plant additives 14.0, oat flour 7.7, eggs 4.3; Recipe 2 (\%): Cottage cheese 69.0, plant additives 17.0, flakes barley 10.0, eggs 4.0. The proposed approach was effective in optimizing various molded culinary products and represents a methodological basis for finding new innovative technological solutions in the food industry and public catering.
\end{abstract}

Keywords: Children's nutrition; Cheese pancakes; Recipe; Optimization; Desirability function; Nutritional value; Jerusalem artichoke. 


\section{Resumo}

Entre os principais desafios a serem enfrentados na indústria alimentar, está a criação de produtos alimentares com a qualidade e o custo acessível exigidos. Os métodos de modelação computacional resolveram tais tarefas otimizando receitas alimentares com base num determinado conjunto de critérios do produto. No entanto, o problema da otimização das refeições escolares ainda tem de ser resolvido. O queijo cottage e os produtos culinários à base dele são uma valiosa fonte de proteína e cálcio. São particularmente procurados por atenderem à demanda nutricional dos alunos. O objetivo desta investigação é desenvolver produtos culinários moldados com base em queijo cottage (panquecas de queijo) através da convolução de critérios que utilizam a função de conveniência generalizada Harrington-Mecher, a fim de satisfazer as necessidades fisiológicas das crianças em idade escolar. Os componentes utilizados foram: queijo cottage; dois aditivos da alcachofra de Jerusalém: (M1: «Alcachofra de Jerusalém, abóbora, pera» ou M2: Alcachofra de Jerusalém, marmelo, cinzas da montanha); ovo, e componentes secos (flocos de cevada ou farinha de aveia). Os componentes foram combinados com relações específicas e as massas obtidas foram sujeitas às análises estrutural-mecânica e sensorial. Para determinar a equação ideal da dependência do stress crítico da tesoura (stress do rendimento) na composição quantitativa da receita, foi realizada uma análise de regressão, seguida de otimização de vários critérios com base na função de conveniência de Harrington. Foram propostas duas receitas de panquecas de queijo, uma vez que mostraram características de qualidade ótimas do produto final: Receita 1 (\%): Queijo cottage 74,0; aditivos vegetais 14,0; farinha de aveia 7,7; ovos 4,3; Receita 2 (\%): Queijo cottage 69,0; aditivos vegetais 17,0; cevada de flocos 10,0; ovos 4,0. A abordagem proposta é eficaz na otimização de vários produtos culinários moldados e representa uma base metodológica para encontrar novas soluções tecnológicas inovadoras na indústria alimentar e na merenda escolar, no âmbito público.

Palavras-chave: Nutrição infantil; Panquecas de queijo; Receita; Otimização; Função de conveniência; Valor nutricional; Alcachofra de Jerusalém.

\section{Introduction}

Cottage cheese is a valuable food product, as it contains protein, calcium, A, E, and B vitamins, so cottage cheese dishes are recommended for children's nutrition (Dror \& Allen, 2014), (Nezami et al., 2016), (Bjerkness, 2014), (Pozzobon \& Pozzobon, 2019), (Yasin \& Shalaby, 2013).

Cheese pancakes (syrniki) - a popular dish for schoolchildren in Russia, Ukraine and Belarus- are molded culinary products made from cottage cheese, eggs, flour or cereals, possibly with vegetable or fruit additives, and fried in oil or baked in the oven (Mogilny \& Tutelyan, 2015). This research aimed to optimize cheese pancake recipes in order to increase their nutritional value and expand the range of culinary products that limit calcium and protein deficiency in children's nutrition. Thus, wheat flour and semolina (traditional structure-forming components for recipes of cheese pancakes) were substituted by oat flour and barley flakes, which are more beneficial for children's nutrition. Jerusalem artichoke (Helianthus tuberosus L.) was also selected as a plant additive, which is a valuable source of biologically active substances (vitamins, inulin, pectin and mineral compounds) (Ceccarelli et al., 2010; Lattanzio et al., 2009), as well as being cheap and easily found. A comprehensive approach was needed to optimize cheese pancake in line with the quality requirement for school meals, including structural-mechanical properties and the chemical composition.

The challenge facing product developers is related to the ability to choose specific conditions that lead to the creation of a product with the desirable combination of properties (Wu et al., 2000; Shazzo et al., 2010; Lee et al., 2018), considering that combining a group of raw materials has an impact not only on the nutritional value, but also on the physico-chemical, technological and sensory characteristics of the final product (Asioli et al., 2017).

A significant part of the modern methods of food design aimed at developing recipes with simultaneous control correlated with specific final-product indicators (Lisin et al., 2012; Borisenko, 2016), such as the optimization method of a multi-component product using the Linear Programming (LP) method 
(Ryan et al., 2014; Sheibani et al., 2018), as well as the Pareto method for multi-criteria optimization with a relatively low number of evaluation parameters (Fliege et al., 2009; Yu, 1985). Jones et al. (1998) also proposed a sequential optimization of complex models, which are refined according to the expected improvement criterion.

Other methods are also proposed to optimize and balance the composition of multi-component products with the setting of a generalized modeling criterion (Zhang et al., 2019; Dubbelboer et al., 2015; Yu et al., 2018), the characteristic function (Carrasco \& Kotchoni, 2017); and multivariate version of the expected improvement criterion (Henkenjohann \& Kunert, 2007), etc.

However, these methods do not provide an integrated optimization of cheese pancake recipes. Considering the aforementioned issues, developing a methodology for designing molded food recipes by using tools for optimizing structural-mechanical properties and balance the chemical composition may be described a current concern in food production today (Nazni \& Gracia, 2014; Byrne, 2014).

Therefore, the authors proposed a multi-criteria optimization of recipe concerning culinary products (cheese pancake) based on the criteria convolution method using the Harrington-Mecher desirability function (Harrington, 1965; Wu, 2004; Trautmann \& Weihs, 2006). The novelty of this approach consisted of the optimization and integration of nonrelated criteria of nutritional value (the content of protein, fat, vitamins, minerals, energy value) and structural-mechanical properties (critical shear stress).

The advantage of using this method is its "neutrality", i.e., the ability to simultaneously take into account many different quality indicators that often contradict each other, and may use one generalized quantitative indicator. Thus, in turn, this method allows obtaining a final product with the required quality characteristics for schoolchildren's nutrition.

\section{Materials and research methods}

The components used to formulate the molded culinary products were: Cottage cheese GOST 31453 (Eurasian Economic Union, 2013) (for cheese pancakes, cottage cheese made from cow's milk (5\% fat) is used); oat flour GOST 31645 (Eurasian Economic Union, 2012); barley flakes GOST 5784 (Eurasian Economic Union, 1960); eggs GOST 54486 (Eurasian Economic Union, 2011); and two additives from Jerusalem artichoke in the form of an industrial puree (Patent RU 2568502) (Lisovoy et al., 2015) with dry substances $18 \pm 2 \%$ :

M1 « Jerusalem artichoke, pumpkin, pear», M2: «Jerusalem artichoke, quince, mountain ash». As a control, the recipe «cheese pancakes with carrots» which contains (\%) was used as following: cottage cheese - 64; carrots - 11; butter- 4; chicken eggs - 3; semolina - 4; wheat flour - 6; and sugar - 8 (Mogilny \& Tutelyan, 2015).

The recipe components were added in the new formulations within the selected ranges (\%) as following: Jerusalem artichoke additives (0-30); eggs (0-13); oat flour or barley flakes (0-18). Higher content of Jerusalem artichoke and / or eggs converted the cottage cheese mass into liquid, not suitable for molding cheese pancakes. Higher levels of oat flour or barley flakes also negatively affected the flavor and texture of the cottage cheese mass. The masses obtained within these ranges showed organoleptic characteristics close to the traditional cheese pancakes.

The design stages of the culinary molded products were as follows: the study of the structural-mechanical properties of food systems; determining the expression level of the co-impact effect; regression analysis of the dependence of the critical shear stress (yield stress) regarding food systems on the ratio of the recipe components; forming a set of requirements for food systems to produce new food recipes; choice of criteria and optimizing the quantitative recipe composition. 
Experimental studies were carried out using methods of instrumental analysis at Kuban State Technological University, Krasnodar Territory, in Russia. All measurements were triplicated including sample preparation and analysis.

\subsection{Samples preparation and structural-mechanical analysis}

Samples with a mass of $100 \mathrm{~g}$ were prepared as follows: cottage cheese was rubbed through a metal sieve with a hole diameter of $1.5 \mathrm{~mm}$, then combined with other recipe components and blended on a Braun 4191 MQ5177BK (Buffet) $750 \mathrm{~W}$ blender at $20^{\circ} \mathrm{C}$ for $5 \mathrm{~min}$.

M1 or M2 was introduced into cottage cheese by the ratio from $0-30 \%$, the structural-mechanical and sensory properties of the masses obtained were investigated, then eggs were added in an amount ranging from $0-13 \%$ to the samples that showed the optimal structural-mechanical indicators. After testing the critical shear stress of the obtained samples, dry components (oat flour or barley flakes) were added by the ratio from $0-18 \%$ to samples characterized by the optimal structural-mechanical indicators. The masses obtained within these ranges of component ratios were close to the traditional cheese pancakes in terms of sensory characteristics.

The study of the structural-mechanical properties of the prepared samples was carried out on the device "Structurometer ST-2" (Russia, company "Aleiron") according to method 30 (ST-2-30). The critical shear stress of food systems $(\delta, \mathrm{Pa})$ was calculated using the Formula 1 of P.A. Rebinder:

$\delta=\frac{\mathrm{K}_{\mathrm{ocr}} \cdot \mathrm{F}_{\mathrm{ocr}}}{\mathrm{h}^{2}}$,

Where:

$K_{\text {ocr }}$ - cone coefficient, (for an angle of $90=0.159$ );

$F_{\text {oct }}$ - a residual loading force on the indenter "cone", $H$.

$h$ - The indenter penetration depth, $\mathrm{mm}$.

The shear modulus (G, Pa) was calculated according to the Formula 2:

$\mathrm{G}=\mathrm{K}_{\mathrm{ocr}} \frac{\left(\mathrm{F}_{\mathrm{k}}-\mathrm{F}_{0}\right) \sqrt{1^{2}+\mathrm{r}^{2}}}{21^{2} \cdot(\mathrm{h}-\mathrm{r})}$,

$\mathrm{F}_{\mathrm{k}}-$ resistance force to the indenter penetration at the beginning of deformation, $\mathrm{H}$;

$\mathrm{F}_{0}$ - resistance force to the indenter penetration at the end of deformation, $\mathrm{H}$.

The control sample had a critical shear stress $(\delta, \Pi a)$ from 2100,00 to 2800,00 , shear modulus (G, Па) from 1700,00 to 3000,00 .

\subsection{Determination of nutritional and energy value of prepared samples}

Nutritional value included the following indicators: energy value (calorie content); amount of proteins, fats, carbohydrates, vitamins and minerals.

The content of the main nutrients was determined by capillary electrophoresis method on the device (KAPEL-103P) with subsequent processing in the program (Multichrome).

Moisture content, ash, protein, and fat contents of samples were determined using the Association of Official Analytical Chemists (2012) methods. Carbohydrate content was calculated using the following equation:

Carbohydrates $\%=100 \%-($ moisture $\%+$ protein $\%+$ ash $\%+$ lipids $\%)$.

Energy values were determined using the formula: 
Energy value $(\mathrm{kcal} / 100 \mathrm{~g})=4 \times$ protein $(\%)+9 \times$ lipids $(\%)+4 \times$ carbohydrates $(\%)$. The assessment of organoleptic indicators was carried out in accordance with GOST 31986 (Eurasian Economic Union, 2015).

\subsection{Regression analysis}

The data was first checked for linear relationships between responses and factors, then multiple regression analysis (backward stepwise regression) was carried out using Statistica v.10 software to determine the dependence of the critical shear stress on the quantitive recipe composition. By processing a digital array, the following indicators were calculated as following: The arithmetic mean value (M); Standard Deviation (SD) from the arithmetic mean $( \pm \sigma)$; arithmetic mean of error $( \pm \mathrm{m})$; Confidence $t$ and the difference between $t$ and probability $p$; Confidence Interval (CI) for a given level of probability. The final reliability of indicators was calculated using the Student-Fisher R confidence coefficient, taking into account the degrees of freedom. Values were considered significant at $p<0.05$.

\subsection{Multi-criteria optimization of quantitative recipe composition}

Mathcad v.15 software was used to solve the design task.

Taking into account the results of rheological, chemical and regression analyses, the recipe was optimized using the method of Harrington-Mecher desirability function, which is a mathematical method of converting real parameter values into a single dimensionless numerical scale with fixed boundaries from 0 to 1 . (Bukzem et al., 2016; Abayomi et al., 2016). The scale, in turn, was split into 5 sub-ranges as following: from 0 to 0.20 - very bad; from 0.20 to 0.37 - bad; from 0.37 to 0.63 - satisfactory; from 0.63 to 0.80 - good; from 0.80 to 1.00 - very good. This approach could reduce the complexity of the multidimensional optimization task (Corzo et al., 2016; Akteke-Öztürk et al., 2020), and allow not only to assess the absolute values of indicators, but it also could reveal how close they were to the deterioration area. When using desirability functions method, it is important to identify indicators for components that need to be minimized or maximized (Figure 1).

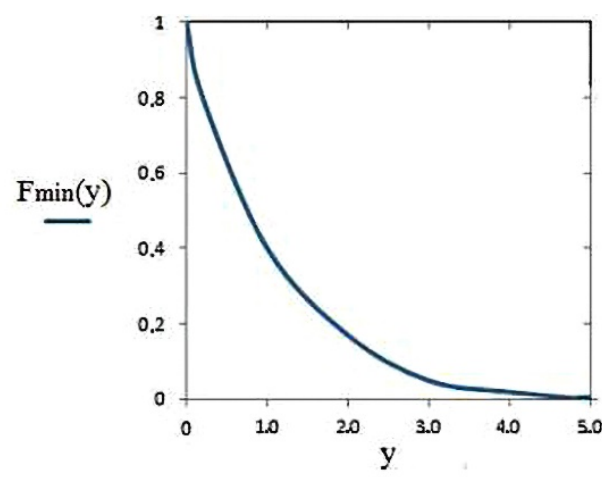

(a

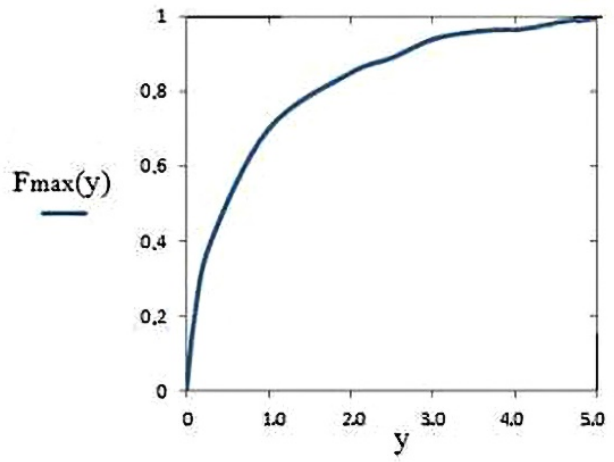

(b

Figure 1. Graphs of minimization (a) and maximization (b) of the dimensionless indicator.

With respect to the physiological needs of school-age children for energy and nutrients (SanPin 2.3 / 2.4.3590-20) (Russia, 2020), along with the maximum and minimum permissible values of structuralmechanical indicators (critical shear stress, shear modulus) of cheese pancakes, the content of protein, calcium, dietary fiber, and vitamins of the recipe mixture were selected to be maximized; in addition to minimizing carbohydrates, fats and energy value. 


\section{Results and discussion}

\subsection{Structural-mechanical analyses of samples}

The results of structural-mechanical analyses of cottage cheese masses combined with M1 or M2, (Table 1) showed that the introduction of M1 or M2 into the cottage cheese mass contributed to the increase of the food system moisture content and reduction of protein quantity as well as the critical shear stress, at the same time, the stickiness and plasticity increased, whereas the viscosity and density decreased, so the food system turns into a liquid state and changes its shape. This is explained by the formation of a solid frame in the food systems of a sufficient concentration of dispersion phase, due to the cohesion forces between particles (Van der Waals forces) (Kruglova et al., 2014; Yakovleva \& Shamkova, 2014), which weaken when the mass fraction of the solvent increases, this leads to a decrease in the critical shear stress, viscosity and density, and to an increase in stickiness, plasticity and shear modulus. The cottage cheese masses with the addition of $15 \%, 20 \%$ of (M1), (M2) respectively had the best taste. They were well-formed and maintained shape, which is an important indicator in the design of molded culinary products, as well as showed average values of critical shear stress and shear modulus.

Table 1. Structural-mechanical indicators of cottage cheese masses combined with M1 or M2.

\begin{tabular}{ccccc}
\hline $\begin{array}{c}\text { Mass fraction of } \\
\text { plant additives.\% }\end{array}$ & Moisture content.\% & $\begin{array}{c}\text { Mass fraction of } \\
\text { protein.\% }\end{array}$ & $\begin{array}{c}\text { Critical shear stress } \\
\mathbf{( \delta . ~ P a ) ~}\end{array}$ & $\begin{array}{c}\text { Shear modulus } \\
\mathbf{( G . ~ P a ) ~}\end{array}$ \\
\hline \multicolumn{5}{c}{ with the addition of (M1) } \\
\hline 5.0 & 58.7 & 16.0 & 2725.21 & 1789.39 \\
\hline 10.0 & 59.52 & 15.32 & 2540.21 & 2029.0 \\
\hline 15.0 & 60.33 & 15.53 & 2410.90 & 2169.52 \\
\hline 20.0 & 61.15 & 14.95 & 2363.42 & 283.56 \\
\hline 25.0 & 61.96 & 14.36 & 2188.03 & 3434.63 \\
\hline 30.0 & 62.78 & 13.78 & 2085.36 & 3810.73 \\
\hline & 63.59 & 13.19 & 2041.48 & 1789.39 \\
\hline 0 & & & 2725.21 & 1831.06 \\
\hline 5.0 & 58.7 & 16.0 & 2692.61 & 1985.34 \\
\hline 10.0 & 59.33 & 15.42 & 2573.49 & 2093.97 \\
\hline 15.0 & 60.18 & 15.65 & 2487.38 & 2375.44 \\
\hline 20.0 & 61.0 & 15.03 & 2364.79 & 2630.87 \\
\hline 25.0 & 61.84 & 14.81 & 2278.05 & 2967.12 \\
\hline 30.0 & 62.51 & 13.95 & 2198.74 & \\
\hline
\end{tabular}

The effect of adding eggs on the structural-mechanical properties of (cottage cheese - Jerusalem artichokebased additives) masses are shown in Table 2.

Adding eggs increased the system moisture content, which led to a decrease of the critical shear stress, and an increase in the shear modulus, the viscosity and density of samples decreased, plasticity and stickiness increased, which is undesirable in the formulation of molded products. Samples with a mass fraction of eggs from (3.0 to 5.0\%) had low formability and shape instability, samples with a mass fraction above $5.0 \%$ were not molded and had a liquid-like consistency. 
Table 2. Structural-mechanical indicators of the cottage cheese with the addition of Jerusalem artichoke-based additives and eggs.

\begin{tabular}{|c|c|c|c|c|c|}
\hline $\begin{array}{c}\text { Mass fraction of } \\
\text { eggs. } \%\end{array}$ & Moisture.\% & Protein.\% & $\begin{array}{c}\text { Ratio of } \\
\text { moisture and } \\
\text { protein in the } \\
\text { product }\end{array}$ & $\begin{array}{l}\text { Critical shear } \\
\text { stress ( } \delta . P a)\end{array}$ & $\begin{array}{l}\text { Shear modulus } \\
\text { (G. Pa) }\end{array}$ \\
\hline \multicolumn{6}{|c|}{ cottage cheese mass with $15 \%$ (M1) } \\
\hline 0 & 61.15 & 14.95 & 4.09 & 2363.42 & 2293.56 \\
\hline 3.0 & 62.10 & 13.92 & 4.46 & 2362.90 & 2376.61 \\
\hline 5.0 & 62.33 & 13.90 & 4.48 & 2358.79 & 2388.22 \\
\hline 7.0 & 62.55 & 13.88 & 4.50 & 2354.43 & 2418.15 \\
\hline 9.0 & 62.77 & 13.86 & 4.52 & 2342.08 & 2429.92 \\
\hline 11.0 & 62.97 & 13.84 & 4.54 & 2339.93 & 2452.03 \\
\hline 13.0 & 63.17 & 13.81 & 4.57 & 2316.92 & 2478.67 \\
\hline \multicolumn{6}{|c|}{ cottage cheese mass with $20 \%$ (M2) } \\
\hline 0 & 61.84 & 14.81 & 4.18 & 2364.79 & 2375.44 \\
\hline 3.0 & 63.09 & 13.26 & 4.76 & 2263.80 & 2678.21 \\
\hline 5.0 & 63.30 & 13.25 & 4.78 & 2251.41 & 2681.19 \\
\hline 7.0 & 63.50 & 13.24 & 4.80 & 2245.40 & 2699.62 \\
\hline 9.0 & 63.70 & 13.23 & 4.81 & 2236.25 & 2720.21 \\
\hline 11.0 & 63.88 & 13.22 & 4.83 & 2223.04 & 3775.67 \\
\hline 13.0 & 64.06 & 13.21 & 4.85 & 2204.31 & 3792.84 \\
\hline
\end{tabular}

In addition, the dry components (oat flour or barley flakes) was added to the masses obtained.

This stage of modelling defines the expression level of the co-impact effect, when the value of an indicator is determined not so much by the individual components but by their mutual influence. The emphasis should not be on the expression of one component, but on the inclusion of several basic indicators in a dimensionless criterion or specific criteria. Results showed (Table 3) that adding dry ingredients had a positive effect on the consistency of the combined masses (cottage cheese, plant additives, eggs), since they increased the critical shear stress, improved formability, stability, and the samples plasticity, in addition to reducing viscosity and shear modulus owing to decrease in moisture content, furthermore, the use of barley flakes or oat flour enhanced fiber and minerals content in the final product. Defined acceptable ranges were as following: for recipe 1: adding (6.0 to $9.0 \%$ ) of oat flour to the mass of $(85.0 \%$ of cottage cheese, $15.0 \%$ of plant additives M1, eggs 3.0-5.0\%); and for recipe 2: adding ( 9.0 to $12.0 \%$ ) of barley flakes to the mass of $(80.0 \%$ of cottage cheese, $20.0 \%$ of plant additives M2, eggs 3.0-5.0\%). Such combined masses are characterized by good sensory characteristics, and well retained form.

\subsection{Regression analysis}

The results of the regression analysis (backward stepwise method) are shown in Table 5. Probability of null hypotheses for the coefficient of the regression equation ( $p$-level) was zero.

Based on the results obtained in Table 4, two regression equations were derived:

For recipe 1 (cottage cheese, plant additives, egg, and oat flour) (Equation 3):

$y=680,0817+20,2646 x_{1}+13,3013 x_{3}+20,2666 x_{4}$ 
A comprehensive approach to design molded culinary products using cottage cheese for school meals

Timofeevna, S. N. et al.

Table 3. Structural - mechanical indicators of cottage cheese masses with the addition of Jerusalem artichoke additives, eggs, dry components (oat flour or barley flakes).

\begin{tabular}{|c|c|c|c|c|c|}
\hline \multirow[b]{2}{*}{$\begin{array}{c}\text { Mass fraction of } \\
\text { dry } \\
\text { components.\% }\end{array}$} & \multicolumn{5}{|c|}{ Indicator name } \\
\hline & Moisture.\% & Protein.\% & $\begin{array}{c}\text { Ratio of } \\
\text { moisture and } \\
\text { protein in the } \\
\text { product }\end{array}$ & $\begin{array}{l}\text { Critical shear } \\
\text { stress ( } \delta . P a)\end{array}$ & $\begin{array}{l}\text { Shear modulus } \\
\text { (G. Pa) }\end{array}$ \\
\hline oat flour & \multicolumn{5}{|c|}{ cottage cheese mass with $15 \% \mathrm{M} 1$ and $3 \%$ of eggs } \\
\hline 0 & 62.10 & 13.92 & 4.46 & 2362.90 & 2376.61 \\
\hline 3.0 & 60.57 & 13.88 & 4.36 & 2368.83 & 2343.52 \\
\hline 6.0 & 59.11 & 13.83 & 4.27 & 2384.91 & 2232.11 \\
\hline 9.0 & 57.72 & 13.79 & 4.19 & 2393.13 & 2143.53 \\
\hline 12.0 & 56.42 & 13.75 & 4.10 & 2465.98 & 2109.44 \\
\hline 15.0 & 55.18 & 13.71 & 4.02 & 2481.63 & 2087.57 \\
\hline 18.0 & 54.01 & 13.68 & 3.95 & 2567.16 & 2024.72 \\
\hline oat flour & \multicolumn{5}{|c|}{ cottage cheese mass with $15 \% \mathrm{M} 1$ and $5 \%$ of eggs } \\
\hline 0 & 62.33 & 13.90 & 4.48 & 2358.79 & 2388.22 \\
\hline 3.0 & 60.77 & 13.85 & 4.39 & 2361.32 & 2354.33 \\
\hline 6.0 & 59.31 & 13.81 & 4.30 & 2371.25 & 2247.51 \\
\hline 9.0 & 57.93 & 13.77 & 4.21 & 2389.91 & 2161.15 \\
\hline 12.0 & 56.62 & 13.73 & 4.12 & 2455.75 & 2122.06 \\
\hline 15.0 & 55.38 & 13.69 & 4.05 & 2479.93 & 2093.72 \\
\hline 18.0 & 54.20 & 13.66 & 3.97 & 2551.76 & 2035.43 \\
\hline barley flakes & \multicolumn{5}{|c|}{ cottage cheese mass with $20 \% \mathrm{M} 2$ and $3 \%$ of eggs } \\
\hline 0 & 63.09 & 13.26 & 4.76 & 2263.80 & 2678.21 \\
\hline 3.0 & 60.65 & 13.20 & 4.59 & 2364.91 & 2381.72 \\
\hline 6.0 & 59.28 & 13.17 & 4.50 & 2383.93 & 2249.31 \\
\hline 9.0 & 57.97 & 13.14 & 4.41 & 2393.23 & 2152.22 \\
\hline 12.0 & 56.74 & 13.11 & 4.33 & 2451.56 & 2132.32 \\
\hline 15.0 & 55.57 & 13.09 & 4.25 & 2479.83 & 2093.43 \\
\hline 18.0 & 54.46 & 13.08 & 4.16 & 2552.20 & 2036.69 \\
\hline barley flakes & \multicolumn{5}{|c|}{ cottage cheese mass with $20 \% \mathrm{M} 2$ and $5 \%$ of eggs } \\
\hline 0 & 63.30 & 13.25 & 4.78 & 2251.41 & 2681.19 \\
\hline 3.0 & 60.86 & 13.20 & 4.61 & 2361.30 & 2554.34 \\
\hline 6.0 & 59.48 & 13.18 & 4.51 & 2374.74 & 2375.57 \\
\hline 9.0 & 58.18 & 13.15 & 4.42 & 2389.93 & 2161.10 \\
\hline 12.0 & 56.94 & 13.13 & 4.34 & 2424.54 & 2128.25 \\
\hline 15.0 & 55.77 & 13.10 & 4.26 & 2473.51 & 2095.59 \\
\hline 18.0 & 54.66 & 13.07 & 4.18 & 2549.18 & 2043.33 \\
\hline
\end{tabular}

Based on our findings, it was found that cottage cheese masses must meet the following criteria values (Table 4) to obtain cheese pancakes with high consumer properties:

Table 4. The criterion values of cottage cheese regarding mass indicators.

\begin{tabular}{|c|c|c|c|}
\hline \multirow{2}{*}{ Sample name } & \multicolumn{3}{|c|}{ Indicator value } \\
\hline & Moisture to protein ratio & Critical shear stress, $\delta$, Па & Shear modulus, G, Па \\
\hline Recipe 1 & from 4.10 to 4.21 & from 2393.13 to 2465.98 & from 2109.43 to 2143.52 \\
\hline Recipe 2 & from 4.41 to 4.51 & from 2340.74 to 2393.24 & from 2152.21 to 2375.57 \\
\hline
\end{tabular}


Table 5. Regression analysis (Backward stepwise method).

\begin{tabular}{|c|c|c|c|c|c|c|c|c|}
\hline Variables & $\begin{array}{c}\text { Fisher's } \\
\text { exact test }\end{array}$ & $\begin{array}{l}\text { Probability of } \\
\quad \text { null } \\
\text { hypothesis for } \\
\text { F-criterion (p) }\end{array}$ & $\begin{array}{c}\text { Correlation } \\
\text { index } \\
\text { (Multiple R) }\end{array}$ & $\begin{array}{c}\text { Coefficient of } \\
\text { determination } \\
\text { RI (R?) }\end{array}$ & $\begin{array}{c}\text { Adjusted } \\
\text { R }\end{array}$ & $\begin{array}{l}\text { Coefficient of } \\
\text { Regression } \\
\text { equation }\left(a_{n}\right)\end{array}$ & $\begin{array}{l}\text { Student's t } \\
\text { test }\end{array}$ & $\begin{array}{c}\text { Probability } \\
\text { of null } \\
\text { hypothesis for } \\
\text { coefficients of } \\
\text { regression } \\
\text { equation } \\
\text { (p-level) }\end{array}$ \\
\hline \multicolumn{9}{|c|}{ Recipe 1} \\
\hline $\begin{array}{l}\text { values of } \\
\text { coefficient } \\
\text { regression } \mathrm{a}_{0}\end{array}$ & \multirow{4}{*}{118.1198} & \multirow{4}{*}{0} & \multirow{4}{*}{0.98} & \multirow{4}{*}{0.96} & \multirow{4}{*}{0.95} & 680.1926 & 6.800 & $6.0 \times 10^{-6}$ \\
\hline $\begin{array}{l}\text { Cottage cheese } \\
\left(\mathrm{x}_{1}\right)\end{array}$ & & & & & & 20.2629 & 17.229 & $2.7 \times 10^{-11}$ \\
\hline $\operatorname{Eggs}\left(\mathrm{x}_{3}\right)$ & & & & & & 13.2961 & 5.5269 & $5.8 \times 10^{-5}$ \\
\hline Oat flour $\left(\mathrm{x}_{4}\right)$ & & & & & & 20.9157 & 12.350 & $4.5 \times 10^{-9}$ \\
\hline & & & & Recipe 2 & & & & \\
\hline $\begin{array}{l}\text { values of } \\
\text { coefficient } \\
\text { regression } \mathrm{a}_{0}\end{array}$ & \multirow{4}{*}{117.0795} & \multirow{4}{*}{0} & \multirow{4}{*}{0.98} & \multirow{4}{*}{0.95} & \multirow{4}{*}{0.95} & 680.0817 & 6.801 & $6.0 \times 10^{-6}$ \\
\hline $\begin{array}{l}\text { Cottage cheese } \\
\left(x_{1}\right)\end{array}$ & & & & & & 20.2646 & 17.235 & $2.7 \times 10^{-11}$ \\
\hline $\operatorname{Eggs}\left(\mathrm{x}_{3}\right)$ & & & & & & 13.3013 & 5.531 & $5.8 \times 10^{-5}$ \\
\hline Barley flakes $\left(\mathrm{x}_{4}\right)$ & & & & & & 20.2666 & 11.971 & $3.0 \times 10^{-9}$ \\
\hline
\end{tabular}

For recipe 2 (cottage cheese, plant additives, eggs, barley flakes) (Equation 4):

$y=680,1926+20,2629 x_{1}+13,2961 x_{3}+20,9157 x_{4}$

The generalized regression Equation 5, for both recipes was:

$y=680,14+20,3 x_{1}+13,3 x_{3}+20,6 x_{4}$

Regression equation revealed that the following variables:

$\mathrm{x} 1$ (cottage cheese mass), $\mathrm{x} 3$ (eggs mass) and $\mathrm{x} 4$ (mass of oat flour or barley flakes) had a significant influence on the critical shear stress of the recipe mixture.

\subsection{Multi criteria optimization of the recipe mixtures}

The desirability functions for maximizing and minimizing the indicators were calculated by the following Equations 6 and 7:

$$
\begin{aligned}
& F_{\text {min }}(y)=e^{-1 \cdot y} \\
& F_{\text {max }}(y)=1-e^{-1 \cdot y}
\end{aligned}
$$

Where " $y$ " was related to the dimensionless indicator. 
The indicators of nutritional value compose the following matrix (Equation 8):

$$
A_{i, j}=\left(a_{i j}\right)
$$

\section{Where}

$i=1 \ldots n-$ The number of the recipe components,

$j=1 \ldots N-$ The number of indicators of the recipe concerning nutritional value (Figure 2).

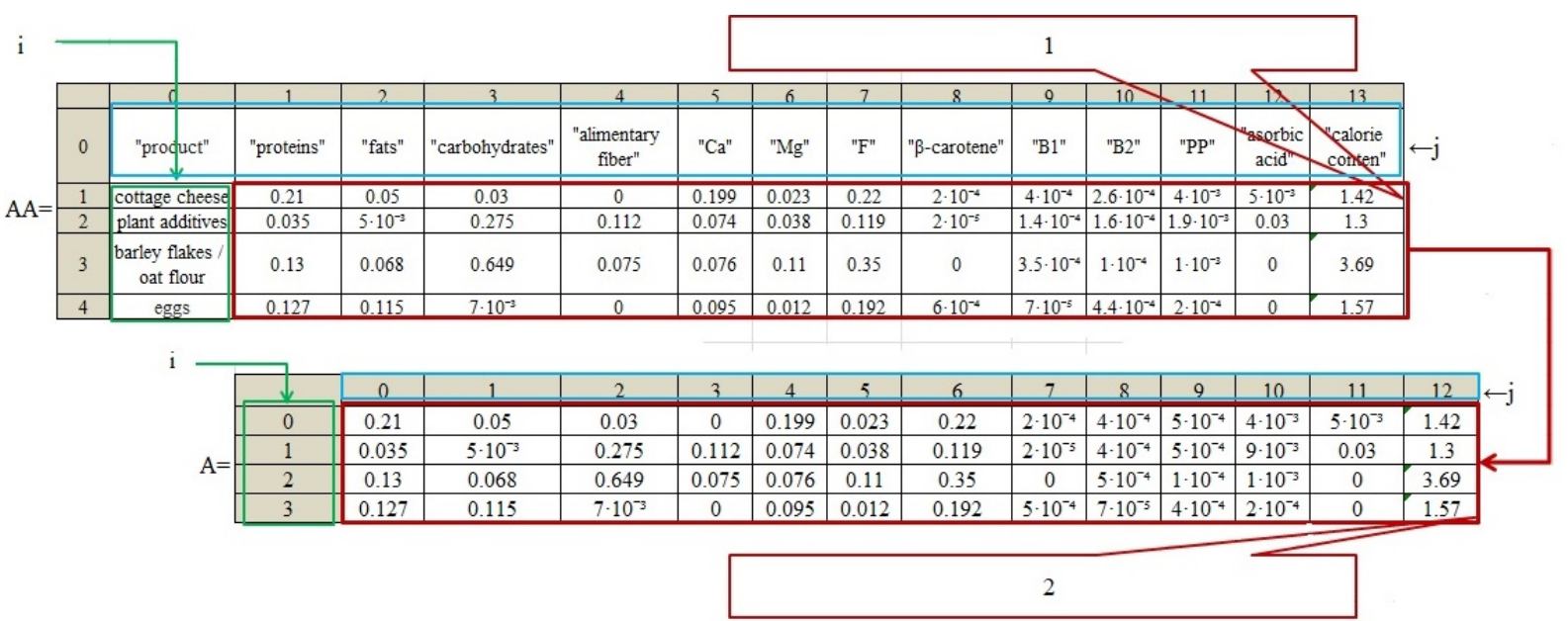

Figure 2. General view of the matrix in the program Mathcad v.15. 1 - Indicators of nutritional value; 2 - matrix

$$
\mathrm{A}_{\mathrm{ij}}=\left(\mathrm{a}_{\mathrm{ij}}\right) \text {. }
$$

The sought vector was denoted by $X=\{x 1, x 2, x 3, x 4\}-$ the vector of mass / the proportion of the recipe components (cottage cheese, plant additives, eggs and barley flakes /oat flour), respectively.

The nutrient content of the recipe mixture was (Equation 9):

$\mathrm{kr}_{\mathrm{j}}(\mathrm{X})=\sum_{\mathrm{i}}\left(\mathrm{A}_{\mathrm{i}, \mathrm{j}} \cdot \mathrm{x}_{\mathrm{i}}\right)$

The average content of nutrients in the mixture (Equation 10):

$\mathrm{M}_{\mathrm{j}}=\frac{\sum_{\mathrm{i}} \mathrm{A}_{\mathrm{i}, \mathrm{j}}}{\mathrm{n}}$,

Evaluation of minimization / maximization of each j-th indicator was determined by (6-10) as follows (Equation 11):

$\mathrm{fC}_{\mathrm{j}}=\mathrm{F}_{\max / \min }\left(\frac{\mathrm{kr}_{\mathrm{j}}(\mathrm{X})}{\mathrm{M}_{\mathrm{j}}}\right)$

Where:

$\mathrm{k}_{\mathrm{rj}}(\mathrm{X})$ : the nutrient content of the recipe mixture:

To maximize the critical shear stress of the recipe mixture, the following Equation 12 was used:

$$
\mathrm{fC}_{\mathrm{N}+1}=\mathrm{F}_{\max }\left(\frac{\mathrm{P}(\mathrm{X})}{\mathrm{Pr}}\right)
$$


Where $P_{r}$ - the average value of the critical shear stress (which is $P_{r}=2429,56$ for $R_{x}$ Module 1; and $\mathrm{P}_{\mathrm{r}}=2383,99$ for $\mathrm{R}_{\mathrm{x}}$ Module 2);

$\mathrm{P}_{(\mathrm{X})}$ - dependence of the critical shear stress on the proportion of recipe components in the mixture (Equation 5).

The convolution (Equation 12 and 13) into the objective function $f(\mathrm{x})$ of optimizing the quantitative recipe composition can be expressed as follows:

$$
\begin{aligned}
& f(x)=F_{\max }\left(\frac{k r(0, x)}{M_{0}}\right) F_{\min }\left(\frac{k r(1, x)}{M_{1}}\right) F_{\min }\left(\frac{k r(2, x)}{M_{2}}\right) F_{\max }\left(\frac{k r(3, x)}{M_{3}}\right) F_{\max }\left(\frac{k r(4, x)}{M_{4}}\right) \\
& \times F_{\max }\left(\frac{k r(5, x)}{M_{5}}\right) F_{\max }\left(\frac{k r(6, x)}{M_{5}}\right) F_{\max }\left(\frac{k r(7, x)}{M_{6}}\right) F_{\max }\left(\frac{k r(8, x)}{M_{7}}\right) F_{\max }\left(\frac{k r(9, x)}{M_{8}}\right) \\
& \times F_{\max }\left(\frac{k r(10, x)}{M_{9}}\right) F_{\max }\left(\frac{k r(11, x)}{M_{10}}\right) F_{\max }\left(\frac{k r(12, x)}{M_{11}}\right) F_{\min }\left(\frac{k r(13, x)}{M_{12}}\right) F_{\max }\left(\frac{P(x)}{P r}\right) .
\end{aligned}
$$

The quality criterion shows the degree of approximation to the "ideal" in percentage:

$K(X)=100 \cdot \sqrt[N+1]{f(X)}$

A comparative assessment of the nutrient content of the mixture and the critical shear stress of Equation 13 and 14 are shown in Figure 3a, b, line 1,

Where:

$\mathrm{f} \mathrm{Cjj}$ - the assessment of each indicator from 0 to $1(\mathrm{jj}=0 \ldots \mathrm{N})$, or it is the actual nutrient content of the mixture, $1-$ it is the nutrient content according to the standard.

The balance criterion had the following values:

For $\mathrm{R}_{\mathrm{x}}$ Module $1=53.5 \%$,

For $\mathrm{R}_{\mathrm{x}}$ Module $2=51.6 \%$.

The desired ratio of the main components $(\mathrm{B} \%)$ for the balance criterion was:

For the $\mathrm{R}_{\mathrm{x}}$ module1: Cottage cheese 74.0, plant additives 14.0, oat flour 7.7, eggs 4.3;

For the Rx module 2: Cottage cheese 69.0, plant additives 17.0, flakes barley 10.0, eggs 4.0;

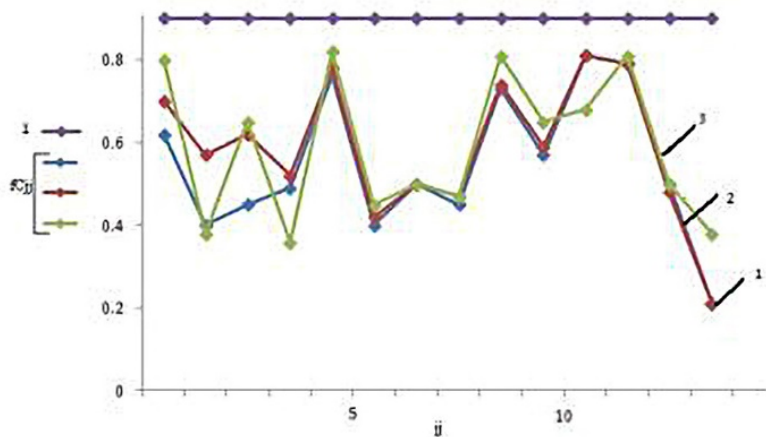

(a

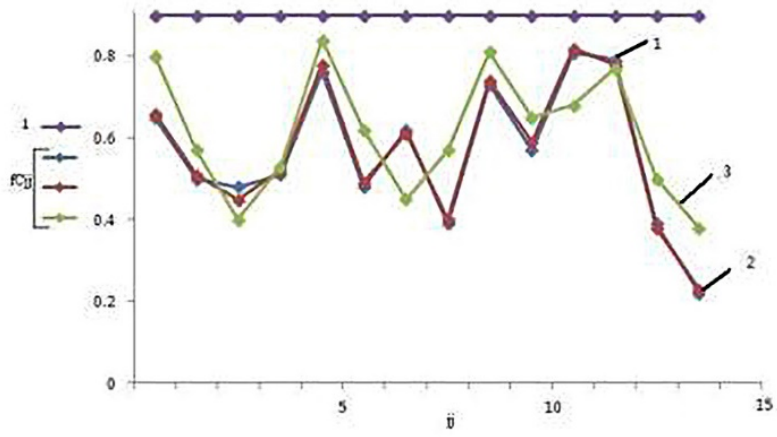

b)

Figure 3. Comparative mixture score for: a) Recipe 1; b) Recipe 2.

These ratios of components were added to develop this cheese pancake recipes for school meals. Our findings were confirmed by an experimental study, and the results were displayed in Table 6 . 
Table 6. Nutritional value of optimized cheese pancakes comparing with the traditional one.

\begin{tabular}{cccc}
\hline Indicator name & $\begin{array}{c}\text { Cheese pancakes with } \\
\text { carrots (control) }\end{array}$ & $\begin{array}{c}\text { Cheese pancakes with the } \\
\text { addition of M1 and oat } \\
\text { flour }\end{array}$ & $\begin{array}{c}\text { Cheese pancakes with the } \\
\text { addition of M2 and barley } \\
\text { flakes }\end{array}$ \\
\hline Mass fraction, $\%$ & & 16.4 & 3.9 \\
\hline protein & 11.8 & 4.5 & 10.7 \\
\hline fat & 9.4 & 9.9 & 117.1 \\
\hline carbohydrates & 15.5 & & 30.9 \\
\hline Minerals, $\mathbf{m g}$ / $\mathbf{1 0 0 g}$ & & 124.7 & 187.5 \\
\hline calcium & 97.4 & 26.3 & 0.1 \\
\hline magnesium & 16.7 & 198.4 & 0.2 \\
\hline phosphorus & 165.7 & & 1.7 \\
\hline Vitamins, $\mathbf{m g} / \mathbf{1 0 0} \mathbf{g}$ & & 0.1 & 172.8 \\
\hline thiamin & - & 0.2 & \\
\hline riboflavin & 0.1 & 0.6 & 172.3 \\
\hline ascorbic acid & 0.2 & & \\
\hline Energy value, $k c a l$ & 224.3 & & \\
\hline
\end{tabular}

It can be seen from the data in Table 6 that the optimized cheese pancakes were characterized by a higher nutritional value compared with the control. Regarding the consumption of one serving of optimizedcheesecakes $(100 \mathrm{~g})$, the daily physiological need of schoolchildren for nutrients was satisfied: from the age of seven to 11 years, protein ranged from $20.3 \%$ to $21.5 \%$, calcium from $10.1 \%$ to $11.0 \%$, and riboflavin from $12.1 \%$ to $14.3 \%$; whereas from the age of 11 to 15 years, protein ranged from $17.4 \%$ to $18.4 \%$, calcium from $9.3 \%$ to $10.1 \%$, and riboflavin from $10.6 \%$ to $12.5 \%$. The cheese pancakes received high organoleptic assessment (4.9 points) in school-age children; seeing that the control was given a lower score (4.7 points).

\section{Conclusions}

Two cheese pancake recipes were optimized according to the basis of the convolution of criteria method by using the Harrington-Mecher desirability function. The final products had a higher nutritional value compared to the control and showed a high degree of acceptance by schoolchildren regarding the sensory characteristics. The proposed approach was effective in developing a wide range of cottage cheese based culinary products (cheesecakes, puddings, casseroles, etc.) for school meals. Further studies can be aimed at making functional cottage cheese and specialized food products for a diverse population, including pregnant women, athletes, and dieters.

\section{References}

Abayomi, O. O., Ruth, A. O., Bala, M. S., \& Twibi, M. F. (2016). A multi-criteria proximal bundle-based optimization approach to chick-mash feed formulation - research \& reviews. Journal of Agriculture and Allied Sciences, 5, 26-33.

Akteke-Öztürk, B., Weber, G.-W., \& Köksal, G. (2020). Generalized desirability functions: A structural and topological analysis of desirability functions. Optimization, 69(1), 115-130. http://dx.doi.org/10.1080/02331934.2019.1570192

Asioli, D., Varela, P., Herslet, M., Langard Almli, V., Veflen Olsen, N., \& Nes, N. (2017). A discussion of recent methodologies for combining sensory and extrinsic product properties in consumer studies. Food Quality and Preference, 56(B), 266-273. http://dx.doi.org/10.1016/j.foodqual.2016.03.015

Association of Official Analytical Chemists - AOAC. (2012). Official methods of analysis of the Association of Official Analytical Chemists (19th ed.). Washington: AOAC.

Bjerkness, S. (2014). Cottage cheese pancakes. Diabetes Self-Management, 31(2), 44-45. PMid:24761549.

Borisenko, A. A. (2016). Theoretical and practical aspects of formulation nutrient-balanced meat products [in Russian]. Technology and Commodity Research of Innovative Food Products, 1, 58-63. 
Bukzem, A. L., Signini, R., dos Santos, D. M., Lião, L. M., \& Ascheri, D. P. R. A. (2016). Optimization of carboxymethyl chitosan synthesis using response surface methodology and desirability function. International Journal of Biological Macromolecules, 85 , 615-624. PMid:26778157. http://dx.doi.org/10.1016/j.ijbiomac.2016.01.017

Byrne C. L. (2014). A first course in optimization. Boca Raton: CRC Press.

Carrasco, M., \& Kotchoni, R. (2017). Efficient estimation using the characteristic function. Econometric Theory, 33(2), 479-526. http://dx.doi.org/10.1017/S0266466616000025

Ceccarelli, N., Curadi, M., Picciarelli, P., Martelloni, L., Sbrana, C., \& Giovannetti, M. (2010). Globe artichoke as a functional food. Mediterranean Journal of Nutrition and Metabolism, 3(3), 197-201. http://dx.doi.org/10.3233/s12349-010-0021-z

Corzo, O., Bracho, N., Rodriguez, J., \& Arias, J. M. (2016). Optimization of salting and smoking catfish (bagre marinus) using response surface methodology. Journal of Aquatic Food Product Technology, 25(3), 358-372. http://dx.doi.org/10.1080/10498850.2013.855286

Dror, D. K., \& Allen, L. H. (2014). Dairy product intake in children and adolescents in developed countries: Trends, nutritional contribution, and a review of association with health outcomes. Nutrition Reviews, 72(2), 68-81. http://dx.doi.org/10.1111/nure.12078.

Dubbelboer, A., Janssen, J., Krijgsman, A., Zondervan, E., \& Meuldijk, J. (2015). Integrated product and process design for the optimization of mayonnaise creaminess. Computer-Aided Chemical Engineering, 37(2015), 1133-1138. http://dx.doi.org/10.1016/B978-0-444-63577-8.50034-6.

Eurasian Economic Union - EAEU (1960). Barley flour specifications (GOST 5784) [in Russian]. Moscow: Technical Regulation of the Customs Union, TR CU.

Eurasian Economic Union - EAEU (2011). Eggs. Terms and definitions (GOST 54486) [in Russian]. Moscow: Technical Regulation of the Customs Union, TR CU.

Eurasian Economic Union - EAEU (2012). Flour for children's nutrition. Specifications (GOST 31645) [in Russian]. Moscow: Technical Regulation of the Customs Union, TR CU.

Eurasian Economic Union - EAEU (2013). Cottage cheese specifications (GOST 31453) [in Russian]. Moscow: Technical Regulation of the Customs Union, TR CU.

Eurasian Economic Union - EAEU (2015). Public catering service. Method of sensory evaluation of catering products (GOST 31986) [in Russian]. Moscow: Technical Regulation of the Customs Union, TR CU.

Fliege, J., Drummond, L. M. G., \& Svaiter, B. F. (2009). Newton's method for multiobjective optimization. SIAM Journal on Optimization, 2(20), 602-626.

Harrington Junior, E. C. (1965). The desirability function. Industrial Quality Control, 21(10), 494-498.

Henkenjohann, N., \& Kunert, J. (2007). An efficient sequential optimization approach based on the multivariate expected improvement criterion. Quality Engineering, 19(4), 267-280. http://dx.doi.org/10.1080/08982110701621312

Jones, J. R., Schonlau, M., \& Welch, W. J. (1998). Efficient global optimization of costly black-box functions. Journal of Global Optimization, 13, 455-492. http://dx.doi.org/10.1023/A:1008306431147

Kruglova I. A., Shamkova N. T., Yakovleva A. V. (2014). Analysis of the dependence of the ultimate shear stress in combined masses based on cottage cheese and the amount of protein and moisture, proceedings of universities. Food technology, (4), 111-113.

Lattanzio, V., Kroon, P. A., Linsalata, V., \& Cardinali, A. (2009). Globe artichoke: A functional food and source of nutraceutical ingredients. Journal of Functional Foods, 1(2), 131-144. http://dx.doi.org/10.1016/j.jf.2009.01.002

Lee, D., Jeong, I., \& Kim, K. (2018). A desirability function method for optimizing mean and variability of multiple responses using a posterior preference articulation approach. Quality and Reliability Engineering International, 34(3), 360-376. http://dx.doi.org/10.1002/qre.2258

Lisin, P. A., Moliboga, E. A., Kanushina, Y. U. A., \& Smirnova, N. A. (2012). Assessment of the amino acid composition of the recipe mixture of food products [in Russian]. Agricultural Gazette Urals, 3, 26-28.

Lisovoy, V. V., Viktorova, E. P., Kornen, N. N., Matvienko, A. N., Chernenko, A. V., \& Lychkina, L. V. (2015). Patent No. 2568502. Bul. No. 32 [in Russian]. Krasnodar: Russian agency for patents and trademarks.

Mogilny, P. M., \& Tutelyan, V. A. (2015). Collection of technical standards - collection of products' recipes for students in all educational institutions [in Russian]. Pyatigorsk: DeLi print.

Nazni, P., \& Gracia, J. (2014). Optimization of fiber rich barhyard millet bran cookies using response surface methodology. International Journal of Agriculture and Food Sciences, 4(3), 100-105.

Nezami, M., Segovia-Siapco, G., Beeson, W. L., \& Sabaté, J. (2016). Associations between consumption of dairy foods and anthropometric indicators of health in adolescents. Nutrients, 8(7), 427. PMid:27420094. http://dx.doi.org/10.3390/nu8070427

Pozzobon, V., \& Pozzobon, C. (2019). Cottage cheese in a diet - a review. Nutrition \& Food Science, 49(6), 1265-1274. http://dx.doi.org/10.1108/NFS-03-2019-0073

Russia. Sanitary and epidemiologic rules and regulations - San PiN. (2020). SanPiN 2.3 / 2.4.3590-20 Sanitary and epidemiological requirements for the organization of public catering [in Russian]. Sanitary and Epidemiologic Rules and Regulations, Moscow.

Ryan, K. N., Adams, K. P., Vosti, S. A., Ordiz, M. I., Cimo, E. D., \& Manary, M. J. (2014). A comprehensive linear programming tool to optimize formulations of ready-to-use therapeutic foods: An application to Ethiopia. The American Journal of Clinical Nutrition, 100(6), 1551-1558. PMid:25411290. http://dx.doi.org/10.3945/ajcn.114.090670 
Shazzo R. I., Kulieva, R. G., Usatikov, S. V., \& Kashkarova, K. K. (2010). Qualimetric aspects of optimization of multicomponent products for baby food [in Russian]. Storage and Processing of Agricultural Raw Materials, 9, 44-46.

Sheibani, E., Dabbagh Moghaddam, A., Sharifan, A., \& Afshari, Z. (2018). Linear Programming: An alternative approach for developing formulations for emergency food products. Journal of the Science of Food and Agriculture, 98(4), 1444-1452. PMid:28776694. http://dx.doi.org/10.1002/jsfa.8612

Trautmann, H., \& Weihs, C. (2006). On the distribution of the desirability index using Harrington's desirability function. Metrika, 63(2), 207-213. http://dx.doi.org/10.1007/s00184-005-0012-0

Wu, F. (2004). Optimization of correlated multiple quality characteristics using desirability function. Quality Engineering, 17(1), 119-126. http://dx.doi.org/10.1081/QEN-200028725

Wu, W., Cui, G. H., \& Lu, B. (2000). Optimization of multiple variables: Application of central composite design and overall desirability. Chin Pharm J, 35(8), 530-532.

Yakovleva, A. V., \& Shamkova, N. T. (2014). Structural, mechanical and thermodynamic properties of food systems based on cottage cheese, Jerusalem artichoke and cereal flakes. Proceedings of the universities. Food Technology, 2-3, 60-63.

Yasin, N. M. N., \& Shalaby, S. M. (2013). Physiochemical and sensory properties of functional low fat cheesecake manufactured using cottage cheese. Annals of Agricultural Science, 58(1), 61-67. http://dx.doi.org/10.1016/j.aoas.2013.01.009

Yu, P., Low, M. Y., \& Zhou, W. (2018). Design of experiments and regression modelling in food flavour and sensory analysis: A review. Trends in Food Science \& Technology, 71, 202-215. http://dx.doi.org/10.1016/j.tifs.2017.11.013

Yu, P.-L. (1985). Multiple-criteria decision-making: Concepts, techniques and extensions. New York: Springer. http://dx.doi.org/10.1007/978-1-4684-8395-6.

Zhang, X., Zhou, T., Zhang, L., Fung, K. Y., \& Ng, K. M. (2019). Food product design: A hybrid machine learning and mechanistic modeling approach. Industrial \& Engineering Chemistry Research, 58(36), 16743-16752. http://dx.doi.org/10.1021/acs.iecr.9b02462 